に X 線治療を加へた所, 臨床上飞も軽快を示した例 では血清の蛋白像の変化が正常化の方向を示した。

\section{2. 単相電源に於ける線管電源の線質に及ぼす} 影響

横倉誠次郎・久保田芳男 竹内 正合・関, 昌夫

第 15 回日本医学放射線学会総会, 昭 31.4 月 単相電源に於ては，管電流波形が管電圧及び管電流 の変化江伴つて異る為江, 電圧の分布状態江変化を及 ぼし，依つて線質に影響を及ぼす事を理論，実験的に 証明した。

\section{3. 頸部淋巴線結核の血清蛋白とそのレ線照射 による影響について}

$$
\text { 土屋 豊・吉野 純男 }
$$

第 6 回電気泳動研究会東部部会, 昭 31 年 6 月

1. 江於て, 述べた後, 更に経過観察をした例につい てのべ，その臨床病因論的意義を補呈した。

\section{4. 放射線の血漿蛋白への影響について(第 1 報)}

$$
\text { 土屋 豊・吉野 純男 }
$$

第7 回電気泳動研究会総会 昭 31 年 11 月

家鬼に一時に 1000r，と400rを照射した 2 群につ いて経過を追つてその血清蛋白像の変動炕ついて観察 した結果を報告した。

\section{5. $\mathbf{X}$ 線管の加熱特性について}

水木 清・久保田芳男

竹内 正合・関 昌夫

第 69 回順天堂医学会例会, 昭 31 年 9 月

\section{6. 平行移動方式断層撮影に於ける缐管の移動 角度による配量分折（第 1 報）}

第 69 回順天堂医学会例会, 昭 31 年 9 月

\section{7. 断層撮影に於ける $\mathbf{X}$ 線管の移動角度によ る配量分布（第 1 報）}

竹内正合・土屋 豊・水木 清 久保田芳男・関 昌夫

第 85 回日本医学放射線学会関東部会, 昭和 31 年 12 月

今回は平行移動式による照射野中心に於て，照射角 度方向によつて，線量分布の様子が如何になるかを理 論式並びに，フィルム黒化度法による実験によつて検 討した.

\section{8. 著明な石灰沈着を来たしたリンパ腺結核症 の 1 例}

順天堂大学医学部第 2. 外科 間 狩 孝

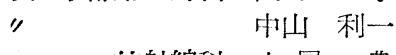

放射線科 土屋 豊

順天堂医学雑誌, 2巻, 4号, 1956

\section{編 輯 後 訅}

これまで本誌の編集の世話をしていた真島教授がア メリカへ留学飞行かれるので代つて本誌の編集の和手 伝をすることになつたが，もともと不馴れのことです から御協力を御願いします。

本誌の発刊もこれで第 3 巻に入るが，一層の充実が 期待されるので良い論交をどしどし出して鿓いたい。 近い将来浮位審查陮も期待されるので学位論交が多 くなること思われる。の時にはるつと考光なけれ ばならぬこともあるが出来るだけ充実した発表機関と して存分の御利用を願います。

学問的に価值高きものであることは勿論，特色ある 研究雑誌としたい，それには多くの良い論交を得て初 めて出来るので，他の專門誌に出されるような良き論 文も出して苜いたい。

日本が国連加盟に成功し国際社会に飛躍寸る年に当 り, この雑誌も飛躍的発展が期待されるものにしたい ものである.

(S. M.)
真島教授渡米の為, この雑誌の編輯を引受けること になつた. やつてみると不手際な所が多く, 表の大き さその他まづかつた点が眼立つが，敃許しを願いたい。 1 号が終るとすぐ 2 号の事が気になるが，手もとには 今の所原著が 2 篇だけしかない，原稿の数がふえて。 他の雑誌のように活字を小さくしなければならない時

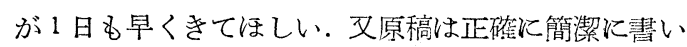
てほしい，編輯員も足りないので，その都度著者隹硲 めたくても，時間に追はれて，つい原稿通りで我慢し て了ろが，何ケ月もの精華であると思うと著者にも申 訳なく又，編輯する者としても残念である．佮今度か ら原著，報告の表紙と学会抄録及び教室業績の用紙を 作つたので利用して戴きたい。

(K. K.)

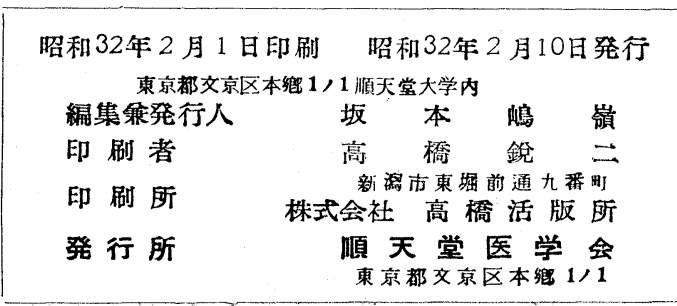

